\title{
Nutrient requirement for bold seeded confectionery groundnut (Arachis hypogaea L.) under irrigated condition
}

\author{
P.M. VAGHASIA* AND V.B. BHALU \\ Main Oilseeds Research Station (J.A.U.) JUNAGADH (GUJARAT) INDIA \\ (Email:pmvjnd@rediffmail.com)
}

\begin{abstract}
A field experiment was carried out during the summer seasons of 2011-12, 2012-13 and 2013-14 at the Main Oilseeds Research Satiation, Junagadh Agriculture University, Junagadh to determine the optimum nutrient requirement for confectionery groundnut to obtain higher productivity and profitability on medium clay soil under irrigated condition. The experiment consisted of nine treatments viz., two nitrogen levels, two potassium levels, two levels of sulphhur and control. Experiment was laid out in Randomized Block Design with four replications. Based on yield and yield components data, it was concluded that treatment $\mathrm{N} @$ $50 \mathrm{~kg} / \mathrm{ha}, \mathrm{K} @ 50 \mathrm{~kg} / \mathrm{ha}$ and S @ $40 \mathrm{~kg} / \mathrm{ha}\left(\mathrm{T}_{8}\right)$ with recommended dose of phosphorus $\left.(50 \mathrm{~kg} / \mathrm{ha})\right)$ gave the highest pod yield of $2770 \mathrm{~kg} / \mathrm{ha}$ and haulm yield of $4557 \mathrm{~kg} / \mathrm{ha}$ with net realization (Rs.85112/ha) and B:C ratio (3.34) which was closely followed by N @ $50 \mathrm{~kg} / \mathrm{ha}, \mathrm{K} @ 25 \mathrm{~kg} / \mathrm{ha}$ and S @ $40 \mathrm{~kg} / \mathrm{ha}\left(\mathrm{T}_{6}\right)$. It is, therefore, suggested that these doses of NPKS fertilizer should be recommended to the farmers in order to raise a healthy and good confectionery groundnut crop and ultimately get highest yields of pods.
\end{abstract}

Key Words : Groundnut, Confectionery, Nutrients requirement, Yield

View Point Article : Vaghasia, P.M. and Bhalu, V.B. (2016). Nutrient requirement for bold seeded confectionery groundnut (Arachis hypogaea L.) under irrigated condition. Internat. J. agric. Sci., 12 (1) : 81-84.

Article History : Received : 23.11.2015; Revised : 05.12.2015; Accepted : 17.12.2015

* Author for correspondence 